\title{
THE CONSUMER PROTECTION ACT AND THE INNKEEPER'S LIABILITY FOR THE PROPERTY OF THE GUEST
}

\section{Introduction}

Literally thousands of consumer agreements are concluded every day between innkeepers and their guests. For present purposes an innkeeper is understood to be a supplier of accommodation services and, in turn, implies the proprietor of an accommodation establishment, such as a hotel, lodge and bed and breakfast establishment (see Beckerling "Tourism" in Joubert (ed) LAWSA Vol 28 2ed (2012) par 39). (Hereinafter, unless the context requires otherwise, the word "supplier" is used interchangeably with "innkeeper", whereas "consumer" is used interchangeably with "guest".)

It is unfortunately not uncommon that property of some consumers of accommodation services are damaged or lost through theft or other causes whilst making use of these services. As an example may serve a media report (http://www.dispatchlive.co.za/featured/2016/10/26/sex-assault-claims disputed-court/) where the Daily Dispatch reported on an incident stemming from an alleged theft by employees of the Kariega Game Reserve from guests at the Reserve. This perennial problem raises the issue as to the liability of the supplier for loss of or damage to the property of the consumer whilst the latter is making use of the accommodation services of the supplier. In the praetorian edict de nautius, cauponibus et stabulariis the common law provides a specific solution as to the liability of the supplier. The edict, which is a consequence of the contract for accommodation services between the supplier and the consumer of those services, imposes strict liability on the supplier for loss of, or damage to, the property of the consumer. This protection, however, is largely negated by the general practice of expressly excluding the liability imposed by the edict in the consumer agreement between the parties.

The introduction of the Consumer Protection Act 68 of 2008 (CPA) saw a number of specific provisions impacting the relationship between consumer and supplier of accommodation services - such as provisions pertaining to equality (s 8 and 9); privacy (s 11 and 12); cancellation of advance reservations (s 17); and customer loyalty programmes (s 35), to name but a few.

The CPA also has implications for the supplier of accommodation services when it comes to the supplier's liability for the loss of, or damage to, the property of the consumer. This note focuses on two particular aspects. The first considers briefly the impact of the Act on clauses excluding the liability of the supplier for loss or damage to the consumer's property. Provisions of the CPA regulating the use of clauses excluding liability may therefore have relevance for the praetorian edict, as the protection provided by the edict is 
excluded as a standard practice, as stated. The edict, because of the impact of the CPA, therefore may resume its relevance of earlier years.

The second aspect pertains specifically to section 65(2) of the CPA. This provision imposes a duty on suppliers in general to account for the property of the consumer when such property is in possession of the supplier. As a matter of course guests bring property into the accommodation establishment of the innkeeper with which the consumer has contracted. If such property is lost or damaged (through no fault of the consumer) the question arises whether section 65(2) can find application. If it does, it can have significant consequences for both suppliers and consumers, but if not, then an understanding of the impact of the CPA on the use of clauses in a consumer contract excluding liability becomes even more important.

\section{The CPA and clauses excluding the supplier's liability}

The CPA contains a number of provisions that may impact the terms of a consumer agreement excluding the liability of the supplier for damage or loss of property, as well as injury or death of the consumer caused by the supplier. Section 49 and other relevant provisions, such as sections 48 and 51 , and their impact on clauses in a contract that limit or exclude the liability of the supplier were more fully discussed elsewhere and need not be repeated (see Tait and Newman "Exemption Provisions and the Consumer Protection Act, 2008: Some Preliminary Comments" 2014 Obiter 629-643). Suffice it to say that section 49 primarily prescribes the manner in which terms or notices excluding liability are to be drawn to the attention of consumers. Such a term or notice must be in plain language (s 49(3)). The attention of the consumer must be drawn to the term or notice in a conspicuous manner and before entering into an agreement, before entering into the premises or before paying, whichever is the earlier time (s 49(4)). The consumer must also be afforded an adequate opportunity to receive and comprehend the notice or term (s 49(5)). Section 51 prohibits the exclusion of liability of a supplier if the loss is occasioned by gross negligence on the part of the supplier. Section 48, read with regulation 44(3)(a), provides that a term excluding liability of a supplier is presumed unfair if its aim is to exclude liability for personal injury or death. The same presumption then seemingly does not apply in respect of damage to or loss of property.

However, this is where regulation 44(3)(b) may be of relevance. The regulation provides that a term in a consumer agreement is presumed unfair if its purpose or effect is to exclude or restrict "the legal rights or remedies of the consumer against the supplier or another party in the event of total or partial breach by the supplier of any of the obligations provided for in the agreement ..." The impact of this regulation is to make all exemption clauses that are not void for endeavouring to deprive a consumer of a right provided by the CPA, presumably unfair ("Regulation 44" in Naudé and Eiselen (eds) Commentary on the Consumer Protection Act (Revision Service 1 2016) reg 44-16).

The necessary consequence then is that a term that excludes the innkeeper's liability under the praetorian edict is presumed to be unfair. One must consider that the liability of the supplier in terms of the praetorian edict 
flows from the nature of the contract (Stocks \& Stocks (Pty) Ltd $v T J$ Daly \& Sons (Pty) Ltd 1979 (3) SA 754 (AD) 762B-D). The liability imposed by the edict therefore is an implied term of the contract between the innkeeper and the guest. Thus the innkeeper has a duty to restore to the consumer the property of the consumer once the innkeeper has received the consumer and the consumer's property. Failure to do so triggers the strict liability of the edict. A term excluding this liability in the consumer agreement puts such a term within the ambit of regulation 44(3)(b), causing it to be presumed unfair. This presumption causes the burden to prove the fairness of the clause to rest with the supplier. If the supplier is unable to establish the fairness of the said term the result is that the term is considered unfair, unreasonable and unjust and therefore void for being in contravention of section 48 of the CPA (Naudé "Section 52" in Naudé and Eiselen (eds) Commentary on the Consumer Protection Act (Revision Service 1 2016) 52-26). In such a case the edict will apply.

Furthermore, regulation $44(3)(x)$ creates a presumption of unfairness in respect of a term of a consumer contract limiting or excluding a consumer from taking legal action or exercising any legal remedy. This regulation prompts De Stadler to comment that "[t]he wording of reg $44(3)(x)$ is so wide that one may argue that many (if not most) exclusions of liability would fall within its scope" (De Stadler Consumer Law Unlocked (2013) 125). Although terms in a consumer contract excluding the supplier's liability are not prohibited per se and although one may question the apparent overlap between the various regulations, the legislature clearly wanted to make sure that the supplier bears to burden to establish the fairness of a term excluding liability.

How can the supplier establish fairness? Section 52(2) provides a list of factors to be considered in determining the fairness of a term. It is not clear if this list is a closed list and the view has been expressed that the courts should not treat it as such (Naudé in Naudé and Eiselen (eds) Commentary on the Consumer Protection Act 52-6). (For a most instructive discussion of these factors, see Naudé in Naudé and Eiselen (eds) Commentary on the Consumer Protection Act 52-9-52-21.) Space does not permit a consideration of all the factors in the present context, but a brief consideration of some factors may serve to illustrate arguments that may be raised to establish the fairness, or otherwise, of including a term which excludes the protection of the praetorian edict. For current purposes the factors mentioned in section 52(2)(b), (c), (d), and (e) are considered briefly.

\section{Section 52(2)(b): Nature of the parties}

The provision holds that the court must consider the nature of the parties, their relationship to each other and their relative capacity, education, experience, sophistication and bargaining position. Naudé in Naudé and Eiselen (eds) Commentary on the Consumer Protection Act 52-11) states that " $[\mathrm{t}]$ hese factors relate to procedural unfairness, that is, to the circumstances surrounding the conclusion of the particular contract, which is likely to vary from consumer to consumer." One only needs to contrast a seasoned South African business person who travels often and stays at the same hotel regularly at one end of the spectrum, with a senior citizen 
travelling and visiting South Africa for the first time and with only a rudimentary capability in the English language at the other end, to get a sense of the relatively weak bargaining position the latter traveler may be in. Could this traveler reasonably be expected to know about the potential impact of excluding liability?

\section{Section 52(2)(c): Circumstances that existed or were reasonably foreseeable at the time the agreement was made}

Only circumstances that both parties knew about or were reasonably foreseeable are relevant (Naudé in Naudé and Eiselen (eds) Commentary on the Consumer Protection Act 52-13). Thus if both parties are aware that the establishment (or area) is suffering from a spate of thefts such fact will be relevant to argue that excluding liability in the particular situation is fair. However, where the consumer is unaware of the situation, but the supplier not, then this will be pertinent in determining whether excluding the supplier's liability will be fair or not (see for instance the facts in Gabriel $v$ Enchanted Bed and Breakfast 2002 (2) SA 597 CPD).

\section{Section 52(2)(d): Conduct of the parties}

Processing consumers, who are checking into their holiday or business accommodation as quickly as possible, is often regarded as effective service - and frankly, consumers generally do not want to read long documents in fine print upon arrival at an accommodation establishment. However, getting consumers to sign the required contract documentation blindly may well be the exact opposite of being effective if that contract is challenged. As Naudé in Naudé and Eiselen (eds) Commentary on the Consumer Protection Act 52-14) suggests, suppliers should train front desk personnel to encourage consumers to read the registration form (contract), or at least draw the attention of the consumer to clauses in the contract excluding liability of the supplier or imposing liability on the consumer. Such a term should in any event be conspicuous and in plain language, and the consumer must be given adequate opportunity to read and understand the terms as is required by section 49. It is submitted that in the context of the accommodation segment of the tourism industry, the initial interface between the consumer and the supplier, be it through a website or at the front desk, is critical in how the information is made available to the consumer and may impact significantly on the fairness of excluding liability.

\section{Section 52(2)(e): Negotiation between the parties}

Clauses excluding the liability of suppliers are mostly a standard term of the contract between the supplier and the consumer and as such not open to negotiation. Naudé in Naudé and Eiselen (eds) Commentary on the Consumer Protection Act 52-15 points out that "[i]t is reasonable and to be expected that suppliers would instruct their employees who deal with consumers to contract with consumers only on the controlled basis of the firm's standard terms and not on terms to be negotiated with consumers." This certainly will be the case for most hotels, lodges and the like. The 
situation may be different in respect of individually owned bed-and-breakfast establishments where a greater amount of negotiation may be possible. The risk to which the supplier is to be exposed in the absence of the exemption clause is relevant, as is the ability of the supplier to insure against the risk (see Naudé in Naudé and Eiselen (eds) Commentary on the Consumer Protection Act 52-16). It may be reasonable to expect the supplier to insure against the risk and therefore the exemption provision may be unfair. Of course, it may also be reasonable to expect of a consumer to insure against foreseeable risks. Whether the consumer indeed was advised timeously to consider insuring him- or herself can be a relevant consideration (Naudé in Naudé and Eiselen (eds) Commentary on the Consumer Protection Act 5216). However, advising a consumer to take out insurance should not be sufficient to escape liability, at least not as a factor in isolation.

\section{Section 65(2) of the CPA and the supplier's duty to account for the consumer's property}

Eiselen ("Section 65" in Naudé and Eiselen (eds) Commentary on the Consumer Protection Act (Original Service 2014) 65-3) points out that the

"scope of s 65 includes payment of prepaid certificates, vouchers and credits or prepaid services and access to facilities made in terms of ss63 and $64, \ldots$, but it goes further because it also includes situations where the supplier takes physical control or possession of goods belonging to a consumer. This is typically the case where goods have been returned to the supplier for repair, where goods are taken to the supplier for inspection, servicing or alteration, where goods are deposited with the supplier for safekeeping or where goods are delivered to the supplier for transportation."

When considering the scope of section 65(2) of the CPA, the application of the provision to the relationship between the innkeeper and his or her guests may not be first and foremost in one's mind. It is proposed that section 65(2) does indeed apply to the relationship between innkeeper and guest and that such application conceivably could have implications for a supplier's liability in respect of consumers in at least three scenarios. Firstly, accommodation establishments often require that deposits be paid when advance bookings or reservations are made. Secondly, consumers may be provided with a service in terms of which valuable items in particular can be handed to the supplier for safe keeping. The third scenario is one of consumers bringing their property into such establishments as a matter of course when staying there without specifically handing it to the supplier. If it should happen that the property in the latter scenario is damaged or lost, then the praetorian edict de nautius, cauponibus et stabulariis may find application. The question is whether section 65(2) would find application also in this specific scenario.

However, before considering the impact section 65(2) may have in these scenarios it is relevant to consider briefly the approach required when interpreting the CPA. 


\section{Interpretation}

Whether section 65(2) applies or not in a particular situation, requires a process of legal interpretation. The courts, in a line of decisions, have expressed themselves on the "emerging trend in statutory construction" referred to in Bato Star Fishing (Pty) Ltd v Minister of Environmental Affairs (2004 (4) SA 490 (CC) par 90). In Natal Joint Municipal Pension Fund v Endumeni Municipality (2012 (4) SA 593 (SCA) par 18) the Court (per Wallis JA) stated the approach to interpretation in the following terms: "The present state of the law can be expressed as follows: Interpretation is the
process of attributing meaning to the words used in a document, be it
legislation, some other statutory instrument, or contract, having regard to the
context provided by reading the particular provision or provisions in the light of
the document as a whole and the circumstances attendant upon its coming
into existence ... The "inevitable point of departure is the language of the
provision itself', read in context and having regard to the purpose of the
provision and the background to the preparation and production of the
document."

(See also in Bakgatla-Ba-Kgafela Community Property Association $v$ Bakgatla-Ba-Kgafela Tribal Authority 2015 (6) SA 32 par 34-36; Department of Land Affairs $v$ Goedgelegen Tropical Fruits (Pty) Ltd [2007] ZACC 12; 2007 (6) SA 199 (CC); 2007 (10) BCLR 1027 (CC) par 53; also Attachmate Corporation v Minister of Water and Environmental Affairs [2015] JOL 33244 (SCA) par 14; Bothma-Batho Transport (Edms) Bpk v Bothma \& Seun Transport (Edms) Bpk 2014 (2) SA 494 (SCA) par 10-12).

The CPA in section 2(1) provides that the Act must be interpreted in a manner that gives effect to the purposes of the Act as set out in section 3 , which is, generally, the promotion and advancement of the social and economic welfare of consumers (see Eskom Holdings Limited $v$ HalsteadCleak [2016] ZASCA 150; 2017 (1) SA 333 (SCA) par 12; see also De Stadler "Section 2" in Naudé and Eiselen (eds) Commentary on the Consumer Protection Act (Revision Service 1 2016) 2-4.) Section 4(2)(b), in turn, enjoins the National Consumer Tribunal and the courts to promote the spirit and purposes of the Act. In Eskom Holdings Limited v Halstead-Cleak (supra par 16) the Supreme Court of Appeal states that "[f]rom the definitions, Preamble and purposes of the Act, it is clear that the whole tenor of the Act is to protect consumers."

Specifically in respect of the CPA the Court in Imperial Group (Pty) Ltd t/a Auto Niche Bloemfontein v MEC: Economic Affairs and Tourism ([2016] ZAFSHC 105 par 27) confirmed that a reading of the long title of the CPA, its preamble and sections 2 to 4 confirm that the Act is concerned primarily with the social and economic welfare of consumers in a market-based society. De Stadler (in Naudé and Eiselen (eds) Commentary on the Consumer Protection Act 2-4) also argues that "in a dispute regarding any unclear portion of the Act, interpretations that favour consumers will override those that favour suppliers."

The afore-going approach finds further support in section 4(3), which states that: 
"If any provision of this Act, read in its context, can reasonably be construed to have more than one meaning, the Tribunal or court must prefer the meaning that best promotes the spirit and purposes of this Act, and will best improve the realisation and enjoyment of consumer rights generally, and in particular by persons contemplated in section 3(1)(b."

In Vousvoukis v Queen Ace CC trading as Ace Motors ([2016] JOL 35677 (ECG) par 91) the Court concluded "that the purpose of the Act is generally to promote and advance the social and economic welfare of consumers and, in the event of any ambiguity in the provisions of the Act, a court interpreting it must prefer the meaning referred to in section 4(3)."

Delport ("Problematic Aspects of the Consumer Protection Act 68 of 2008 in Relation to Property Transactions: Linked Transactions, Fixed Term Contracts and Unsigned Sale Agreements" 2014 Obiter 68) warns, correctly it is submitted, that the CPA seeks to protect consumers against exploitation, unfair treatment and unscrupulous business practices, but that the fair treatment of the consumer does not require the protection of the consumer at all costs. The learned author proposes that a sensible interpretation of the CPA requires that a balance between the legitimate interests of the consumer and that of the supplier be struck (Delport 2014 Obiter 68-69). Thus, when interpreting the CPA the interpreter must, bearing in mind the purposes of the Act, strive to balance the legitimate interests of the supplier and the consumer, but if in this process the interpreter is confronted with an ambiguity the Act is clear that the interests of the consumer must prevail.

\section{Section 65(2) and the innkeeper's liability for property of the guest}

Section 65(2) of the CPA states:

"When a supplier has possession of any prepayment, deposit, membership fee, or other money, or any other property belonging to or ordinarily under the control of a consumer, the supplier-

(a) must not treat that property as being the property of the supplier;

(b) in the handling, safeguarding and utilisation of that property, must exercise the degree of care, diligence and skill that can reasonably be expected of a person responsible for managing any property belonging to another person; and

(c) is liable to the owner of the property for any loss resulting from a failure to comply with paragraph (a) or (b).

Above reference has been made to three typical scenarios that may present themselves in the context of the innkeeper-guest relationship. These are the payment (and holding) of a deposit paid in advance; the handing of specific items to the supplier to hold; and the situation where the consumer brings property into the accommodation premises but keeps the property with the consumer (such as in the room occupied by the consumer).

The obligations imposed by section 65(2) are considered with reference to the three scenarios mentioned. 


\section{Section 65(2)(a)}

The first duty imposed by section 65(2)(a) is that it requires of the supplier not to treat the property of the consumer as the property of the supplier. This requirement should not give rise to too many practical problems when it comes to property brought onto the premises of the supplier. Whether the consumer physically hands the property to the supplier or the property remains in the hands of the consumer (or in the room of the consumer) the supplier may not make use of that property as if it is the property of the supplier. For example, the staff of the accommodation establishment cannot wear the clothing or jewellery of the consumer, use of the make-up, clothing, cellphones or cameras of the guests as if it is the property of the supplier. Staff using the make-up of the consumer or making calls on the cellphone of the consumer will constitute a breach of the duty not to treat the consumer's property as that of the supplier. Not only will this constitute prohibited conduct, but in terms of section 65(2)(c) the supplier is liable for any loss suffered by the consumer for a breach of the duty imposed by section 65(2)(a).

It will remain a factual question in each case to determine whether the supplier used the property of the consumer as that of the supplier. It is probably safe to say that this aspect, or duty, should not pose serious legal problems in practice, except insofar as it relates to money. The problem in the latter instance is that money received into the cash register or bank account of the supplier, such as when a deposit is paid in advance, through the process of confusio becomes indistinguishable from the money of the supplier, making compliance with section 65(2)(a) virtually impossible. See the discussion by Eiselen in Naudé and Eiselen (eds) Commentary on the Consumer Protection Act 65-3-65-4 and 65-5-65-6.) This aspect does require clarification.

\section{Section 65(2)(b)}

Section 65(2)(b) of the CPA imposes a duty of care on the supplier when in possession of the property of a consumer or property ordinarily under the control of the consumer. This duty entails that in the handling, safeguarding and utilisation of such property the accommodation establishment and its staff must exercise a degree of care, diligence and skill that can reasonably be expected of a person responsible for the managing of any property belonging to another person. A consumer will have to establish fault, at least in the form of negligence, to hold a supplier liable under section 65(2).

The common law contains rules regulating the situation where a person receives and holds property belonging to another. In terms of the common law rules the person holding the property (depositary) must exercise due care and diligence in looking after the property. A breach of this duty makes the depositary liable to the depositor for loss or damage to the property. Thus it became standard practice for depositories to exclude or substantially limit the rights of depositors in the standard terms of an agreement of depositum (see Eiselen in Naudé and Eiselen (eds) Commentary on the Consumer Protection Act 65-4-65-5). However, the author furthermore points out that the rights of consumers (such as the depositor) are 
substantially better protected by the CPA through the limitation placed on standard terms employed in consumer contracts to exclude liability of suppliers. An example is section 51(1)(b) which prohibits a term in a consumer contract purporting to waive or deprive a consumer of a right provided for in the CPA (Eiselen in Naudé and Eiselen (eds) Commentary on the Consumer Protection Act 65-5). The conclusion is that section 65(2)(b) provides the depositor with more effective protection than the common law form of depositum.

The rights provided a consumer in terms of section 65(2) are conditional upon the supplier having possession of the property of the consumer. Where the consumer hands to the staff of the accommodation establishment property for the purposes of safekeeping, for instance, and the item is lost or damaged, section 65(2)(b) may regulate the situation, or the praetorian edict. If the contract between the parties is effective in excluding the liability of the supplier, the consumer cannot rely on the strict liability imposed by the edict. However, the consumer will nonetheless be able to make use of section 65(2)(b). If it is found that the supplier acted negligently in breaching the duty imposed by section 65(2)(b), the supplier will have to make good the loss to the consumer as provided in terms of section 65(2)(c). This type of situation, it is submitted, should not give rise to difficult legal problems, at least insofar as the requirement of possession is concerned as there can be little doubt that whilst the supplier was holding the consumer's property in safekeeping, the supplier was in possession of the property.

What is less clear is whether the duty imposed by section 65(2)(b) applies also to the situation where the consumer brings property, such as clothing, jewellery, cameras and electronic equipment, into the premises of the supplier and the property is kept in the consumer's room for use in the normal course of events, that is, it is not physically placed into the hands of the supplier. Does section 65(2) find application in this specific context? This question makes it necessary to consider whether the stated requirement of possession permits or excludes the application of section 65(2) to the specific scenario indicated above. A supplier confronted with a claim in terms of section 65(2) for the loss of or damage to property of a guest where the property was kept in the room of the guest, is certain to argue that he/she, the supplier, was not in possession of the property and, therefore, section 65(2) does not find application. Such an argument may find support in the view expressed by Eiselen (in Naudé and Eiselen (eds) Commentary on the Consumer Protection Act 65-6), who states that the rights provided for in section 65 are extended to all contracts where the property is placed "in the hands of the supplier by the consumer."

To establish possession two requirements must be met. These are that there needs to be effective physical control of the property, and there needs to the intention to derive some benefit from the possession (Van der Walt and Pienaar Introduction to the Law of Property (2016) 202; Badenhorst, Pienaar and Mostert Silberberg \& Schoeman's Law of Property (2006) 276). Badenhorst, Pienaar and Mostert (Silberberg \& Schoeman's Law of Property 273) explain that "[p]ossession can be described as a compound of a physical situation and a mental state involving the physical control (corpus) of a thing by a person and that person's mental attitude (animus) towards 
the thing." And further (Badenhorst, Pienaar and Mostert Silberberg \& Schoeman's Law of Property 273): "Although the minimum requirements of physical control and a specific mental attitude always need to be in place to constitute possession, the exact content of possession will depend on the context in which and the purpose for which it is used." It is clear therefore that the context does play a decisive role in determining whether a person has possession of property or not.

The measure of physical control required to meet the threshold for possession of specific property will depend on various factors, including the nature and purpose of the thing (Van der Walt and Pienaar Introduction to the Law of Property 203; Badenhorst, Pienaar and Mostert Silberberg \& Schoeman's Law of Property 276). The factual context therefore is important to determine the extent and the nature of the physical control that would be considered as sufficient for purposes of establishing the control element (Mostert, Pope, Badenhorst, Freedman, Pienaar and Van Wyk The Principles of the Law of Property in South Africa (2010) 70). A factor that may impact the question whether there is the required physical control is specific customs in special fields (Van der Walt and Pienaar Introduction to the Law of Property 204). This shows that the context is, or can be, a decisive consideration in establishing whether the control element is complied with. The context of the innkeeper and guest is a particular situation. It therefore is instructive to consider the situation prevailing in respect of the praetorian edict.

Of the earliest laws specifically enacted to protect the property of consumers of accommodation services was the praetorian edict de nautius, cauponibus et stabulariis in the first century BC. The edict was originally adopted for reasons of public policy to make travelling possible (Swart $v$ Shaw t/a Shaw Racing Stables 1996 (1) SA 202 (C); Zimmerman The Law of Obligations: Roman Foundations of the Civil Tradition (1990) 516; Van der Bijl "B\&B Establishments, Hotels and the Praetorian Edictum de nautius, cauponibus et stabulariis: cessante ratione legis cessat lex ipsa?" 2006 SALJ 570.) A consumer making use of an innkeeper's services had to deliver his or her property into the custody of the supplier, and then had to depend on the good faith and honesty of the supplier as the consumer had brought his or her property into a sphere under the control of the supplier. Establishing fault on the part of the innkeeper when the consumer's property was damaged or lost was very difficult for the consumer (Zimmerman The Law of Obligations: Roman Foundations of the Civil Tradition 516).

The Court in Davis v Lockstone (1921 AD 154 161) made it clear that the praetorian edict would find application even where the property of the consumer was not specifically handed to the supplier for safe keeping. Thus the fact that the property was brought into the premises of the supplier is considered sufficient compliance with the requirement that the property had to be "received" by the innkeeper (see Voet Commentary on the Pandects 4 92 (Ganes's translation) (1956) 767-768.) According to Voet and the courts it would then appear as if it is accepted that the innkeeper is considered to have possession of the property when the innkeeper has received the property despite the property not being physically handed to the innkeeper. In Davis v Lockstone (supra 158) (per Solomon JA), the Court refers to Voet 
with approval and states that "innkeepers ... carrying on trade by means of their ... hotel ... are presumed to have undertaken the custody of anything put ... into their hotel, although they may not have accepted money for it." In his concurring judgment Juta JA (Davis $v$ Lockstone supra 164) states that "the goods which a person who engages a bedroom in a hotel brings with him must be considered to have been 'received' within the meaning of the Edict although these goods are not specifically handed over to the hotel keeper for safekeeping". The rationale for this approach is explained by the Court in Davis v Lockstone (supra 161) as follows:

"[t]o hold that ... the inn keeper would not be liable for the loss of luggage which had not been specially entrusted to him for safe keeping, would make the law of but little effect, seeing that a guest in an hotel needs his luggage in his room, and consequently could not hand it over to the proprietor for safe keeping."

In light of the afore-going it is submitted therefore that in the specific context where the property of the consumer (guest) is brought into the accommodation establishment, it is received by the supplier (innkeeper) and therefore also is in the possession of the supplier, irrespective of whether the property was handed to the supplier or whether the consumer kept the property in the room occupied. It follows then that there is room to argue that the requirement in section 65(2)(b), namely that the property must be in the possession of the supplier for the duty imposed by the provision to arise, is complied with in the specific context where the consumer did not hand to the supplier the property brought into the establishment, but kept it in the room occupied by the consumer.

If the requirement of possession provided for in section 65(2) reasonably permits more than one interpretation, section $4(3)$ of the CPA instructs that such ambiguity must be resolved by preferring the meaning that best promotes the spirit and purposes of this Act, and will best improve the realisation and enjoyment of consumer rights generally. Important to bear in mind here is the purpose of the CPA, namely that a balance between the legitimate interests of the consumer and that of the supplier be struck when interpreting and applying the Act in a particular context, but if there is ambiguity then the interests of the consumer must prevail. Sight must not be lost also of the public policy consideration that the consumer is placing his or her property in a sphere which the supplier controls. Although it is not suggested that today's innkeepers are unscrupulous suppliers colluding with thieves to steal from travelers making use of accommodation services (as the purpose of the edict was explained in Shaw t/a Shaw Racing Stables supra 204I), the environment into which the consumer ventures is still an environment in the control of the supplier and the consumer has very little, if any, control. Thefts from consumers at accommodation establishments are unfortunately not uncommon. Does allowing the consumer the protection of section 65(2) in such a case unduly favour the consumer to such an extent that there is an imbalance in the different interests? It is believed not. Considering that the protection offered by the praetorian edict generally is excluded by agreement as a matter of course, albeit now subject to the stricter requirements for limitation of liability provided by especially sections 48, 49 and 51, the consumer is left with very little, if any, protection if the consumer brings property into an accommodation establishment and keeps 
the property in the room occupied by the consumer. Van Eeden ( $A$ Guide to the Consumer Protection Act (2009) 4) also then states that it is not surprising that a significant factor in the development of consumer law in general can be "ascribed to legislative responses to business disclaimers of accountability for negative consequences attendant upon their dealings with consumers." Section 65(2) may well be part of such a response. In an environment under the control of the supplier and where any liability of the supplier for loss or damage to the property of the consumer, is routinely excluded, it can hardly be said to be a fair balancing of legitimate interests. Balancing these interests may well require that possession, as a requirement to find liability on the part of the supplier for loss or damage to property of the consumer, be interpreted to mean also that the supplier is in possession of such property if brought into the premises, even if the property was not strictly speaking placed in the hands of the supplier.

Referring to the innkeeper's lien may also be worthwhile. Badenhorst, Pienaar and Mostert (Silberberg \& Schoeman's Law of Property 415) point out that '[i]nnkeepers have a lien over their guests' belongings brought on to their premises for their charges in respect of lodging and meals supplied" (see also Beckerling in Joubert (ed) LAWSA par 43) who states that innkeepers have a lien in respect of property brought into the establishment of the innkeeper. The right of lien only exists if the lien holder is in possession of the property (Badenhorst, Pienaar and Mostert Silberberg \& Schoeman's Law of Property 416). It is submitted that the lien extends not only to property placed in the hands of the supplier but also to property brought on to their premises but kept in the room of the consumer. It would be relatively easy for the supplier to exercise the lien in respect of property kept in the room by, for instance, deactivating the room key provided the consumer thereby denying the consumer further access to the room. Through this Act, it may be argued, the supplier is not taking possession of the property but actually will be extending the physical control element of possession. A form of shared control then changes to a form of exclusive control as the parties, because of a dispute over payment, are now competing for control (see Badenhorst, Pienaar and Mostert Silberberg \& Schoeman's Law of Property 279).

The relevance of the discussion on the lien is that property of the guest brought on to or in to the accommodation establishment, whether placed in the hands of the supplier or not, is considered to be in possession of the supplier for purposes of the innkeeper's right of lien. If such property is considered then to be in possession of the supplier for purposes of the lien, it also must be in possession of the supplier for purposes of section 65(2).

The second requirement to establish possession is presence of an intention to derive some benefit from possessing the property. Badenhorst, Pienaar and Mostert (Silberberg \& Schoeman's Law of Property 279) state in this regards that "[i]t is, however, impossible to give a single comprehensive definition of the mental element of possession as the content thereof depends on the particular legal consequence of possession which one has in mind." Different forms of animus are distinguished. There is the intention to control the property as if the owner (animus domini); the intention to control the property exclusively, with the exclusion of others (animus rem sibi 
habendi); the intention to derive some benefit from controlling the property (animus ex re commodum acquirendi), and the intention to hold a thing without deriving a benefit (animus terendi) (see Badenhorst, Pienaar and Mostert Silberberg \& Schoeman's Law of Property 280). In the specific current context the animus ex re commodum acquirendi is likely the more appropriate form of animus. The supplier does derive benefits from receiving the property, namely a guest (income), and the object of the innkeeper's lien (surety). This form of intention is in any event usually interpreted quite widely (see Badenhorst, Pienaar and Mostert Silberberg \& Schoeman's Law of Property 283; Van der Walt and Pienaar Introduction to the Law of Property 212) point out that "[i]t is fairly widely accepted that in certain circumstances a person can acquire control before being aware that the corporeal aspect of control was established."

\section{Conclusion}

This note considers the impact of the CPA on the liability of an innkeeper for loss of damage to the property of the guest of the innkeeper. Under the common law the praetorian edict imposes strict liability on the innkeeper for any damage or loss of the property of the consumer whilst a guest of the innkeeper, provided of course the loss is not caused by the guest. The liability imposed on an innkeeper by the edict is a natural consequence of the contract between innkeeper and guest. However, the efficacy of the edict is eroded significantly by the standard practice of excluding this liability by agreement. This situation seems to have been impacted substantially by various provisions of the CPA. Excluding the strict liability imposed by the edict is significantly curtailed in that, firstly, section 49 proscribes strict tests of incorporation for clauses excluding the liability of a supplier. These tests, it is submitted, offer the consumer scope to challenge a clause excluding the supplier's liability. Secondly, regulations $44(3)(b)$ and $(x)$ as read with section 48 of the Act, imposes a presumption of unfairness on a contractual term excluding the protection of the praetorian edict. Even if the clause excluding liability passes the incorporation tests provided for in section 49 (and s 51), it will still be presumed to be unfair, with the innkeeper bearing the onus to prove the fairness of the clause. Whether excluding the liability imposed by the edict is fair must be determined on a case-by-case basis. The factors to be considered for determining the fairness of such a contractual term allow for considerable scope to argue the fairness or otherwise, of excluding the liability imposed by the edict. (It is submitted that the supplier may have some difficulty in convincing a court that it is fair to exclude liability.)

Once the innkeeper has successfully established that there was compliance with the incorporation tests and that the clause excluding liability is fair, is the protection of the edict nullified. The consumer potentially may then rely on section 65(2) by establishing that the innkeeper did not meet the required standard of care imposed by the section. This will include proving fault on the part of the supplier. The parties cannot exclude the protection offered by section 65(2).

The question was posed whether the protection provided a consumer in terms of section 65(2) of the CPA extends to the relationship between an innkeeper and a consumer of accommodation services. An argument was 
presented that the innkeeper is in possession of the property of the guest (as required by section 65(2)), even where the consumer keeps the property in his or her room as opposed to placing it in the hands of the supplier. This argument is certainly not without its problems, particularly as the concept of "possession", and its constitutive elements, is difficult to define. However, it is submitted that the requirement of possession in section 65(2) can be interpreted to allow for a meaning in terms of which the supplier is considered to be in possession of the consumers property in the specific context of a guest of an innkeeper and where the guest keeps the property in his or her room as opposed to placing it in the hands of the innkeeper. Such an interpretation extends the protection of section 65(2)(b) in particular, to a consumer who may have very little control over his or her environment. In this the purpose of the CPA is served.

The precise extent to which section 65(2) applies to the relationship between the innkeeper and a guest, does not detract from the considerable impact the CPA has in strengthening the protection provided by the praetorian edict. Consumers of accommodation services may be better protected than ever before.

Mark Tait

Nelson Mandela University, Port Elizabeth 